Zofia Sajdek

\title{
Dlaczego Popper nie był kryptoindukcjonistą
}

\section{Wstęp*}

Czy istnieją autentyczne problemy filozoficzne? Ta kwestia, jak głosi opowieść, poróżniła Karla Poppera z Ludwigiem Wittgensteinem, gdy spotkali się, jedyny raz, w 1946 roku w Cambridge na spotkaniu Moral Sciences Club ${ }^{1}$. Podczas gdy Wittgenstein głosił, że w filozofii mamy do czynienia jedynie z przypadkami, gdy „język świętuje”, które powinno się demaskować, sprowadzając słowa do właściwych im gier językowych - Popper do końca życia utrzymywał, że istnieją kwestie, które są filozoficzne, cechują się głębią, a w dodatku niektóre z nich on sam ostatecznie rozwiązał. Jako pokazowy przykład służył rozstrzygnięty przezeń negatywnie problem indukcji. Jednak niektórzy sądzą, że nie poszło mu tak dobrze, jak uważał.

Celem niniejszego artykułu jest analiza zasadności zarzutu o ukrytą postać indukcjonizmu w związku z wprowadzeniem przez Poppera kategorii prawdoupodobnienia. Krytyczne prześledzenie zarzutów wobec Popperowskiego rozwiązania jest zarazem przyjrzeniem się z kolejnej perspektywy istocie problemu, którego odpowiedniki można znaleźć w każdej epoce. Co mogę wiedzieć

\footnotetext{
*Artykuł jest oparty na fragmentach pracy magisterskiej pt. Karla R. Poppera koncepcja koroboracji i prawdoupodobnienia hipotez w kontekście zarzutu o kryptoindukcjonizm, obronionej w roku 2011 na Wydziale Filozoficznym UPJPII w Krakowie.

${ }^{1}$ Zob. K.R. Popper, Nieustanne poszukiwania. Autobiografia intelektualna, Znak, Kraków 1997, s. 169-170.
} 
o świecie empirycznym, mając do dyspozycji jedynie wiedzę o przeszłych przypadkach? Co powinienem czynić w tej sytuacji, czym kierować się w działaniu praktycznym? I czy mogę spodziewać się czegoś po teorii, która przeszła pozytywnie surowe testy, czy też podobne oczekiwania są z natury swej nieprawomocne? Te trzy pytania, rozgrywające się na płaszczyźnie epistemologicznoetyczno-pragmatycznej, streszczają Popperowską wersję problemu indukcji.

Zaprezentowane w niniejszym artykule stanowiska wybrane zostały pod kątem możliwości odniesienia do kwestii indukcjonizmu Poppera, rzekomego lub faktycznego (to główne pytanie pracy, więc lepiej nie zdradzać zbyt szybko zakończenia). Przedstawiają się następująco:

- Zaczniemy od Davida Hume'a, według którego dla rozwoju wiedzy naukowej indukcja jest nieprawomocna i niezbędna;

- Sam Popper, odnosząc się do tych rozstrzygnięć, twierdził, że indukcja co prawda jest nieprawomocna, lecz jest także zbędna;

- Dla Rudolfa Carnapa indukcja jest nie tylko metodologicznie prawomocna, ale i niezbędna;

- Także zdaniem Imrego Lakatosa zasada indukcji jest prawomocna (z tym, że jako zasada metafizyczna), a także niezbędna, lecz nieobecna w pismach Poppera, gdzie powinna się znaleźć;

- Całkowicie opozycyjnego stanowiska bronił John Watkins, według którego indukcja jest nieprawomocna i zbędna, ale występuje w metodologii Poppera, skąd powinna zostać usunięta ${ }^{2}$.

Skrajna rozbieżność stanowisk wskazuje na to, że spór cechował się ogromną żywotnością. Rozpatrywana w niniejszym

\footnotetext{
${ }^{2}$ Por. J. Watkins, Nauka a sceptycyzm, PWN, Warszawa 1989, s. 228.
} 
artykule kwestia dotyczyć będzie tylko jednego z wątków indukcyjnego zamieszania, a mianowicie możliwości odniesienia nauki do prawdy bez ugruntowania w zasadzie indukcji. Właściwy problem można sformułować następująco: czy powiązanie potwierdzania teorii w eksperymentach ze stopniem prawdoupodobnienia, czyli wskazanie na istnienie podstaw dla nadziei przybliżania się do prawdy w związku ze sprawozdaniami z przeszłych testów, stanowi quasi-indukcyjny pierwiastek w filozofii Poppera ${ }^{3}$ ?

\section{Popper a Hume, czyli o antysceptycyzmie}

„Sceptycyzm, choć logicznie jest bez zarzutu, jest niemożliwy psychologicznie i w każdej filozofii, która udaje, że go akceptuje, zawarty jest element lekkomyślnej nieszczerości" ${ }^{4}$ - pisał Bertrand Russell. Czy rzeczywiście można określić Davida Hume'a mianem „lekkomyślnego” i „nieszczerego” w głoszonych poglądach? A może raczej podobne zarzuty tyczą się jedynie sceptycyzmu w wydaniach akademickim czy pirrońskim? Przyjrzyjmy się jednej ze składowych Hume’owskiego konceptu: tezie głoszaccej, że tylko wiedza dedukcyjna może być uznana za prawomocną. To stwierdzenie prowadzi do faktycznego antynaukowego sceptycyzmu dopiero w koniunkcji z założeniem, jakoby nauka była praktyką indukcyjną.

Problem Hume'a jest taki sam, jak wiele lat później stawiany przez Poppera czy przedstawicieli Koła Wiedeńskiego. Dotyczy uzasadnienia wiedzy o świecie, na podstawie przeszłych faktów (w szczególności przeprowadzonych testów). Podczas gdy Kant określił zagadnienie zdań syntetycznych a priori „problemem Hume'a", to Popper nazywa tak problem indukcji. Hume prezentuje go w kilku wydaniach. Kluczową wersję przedstawił w rozdziale „O wnioskowaniu z impresji o idei” 5 , gdzie zaprezentowane

\footnotetext{
${ }^{3}$ Por. np. A. Chmielewski, Filozofia Poppera. Analiza krytyczna, wyd. Uniwersytetu Wrocławskiego, Wrocław 1995, s. 72.

${ }^{4}$ Cyt za: J. Watkins, Nauka a sceptycyzm, dz. cyt., s. 13.

${ }^{5}$ Zob. D. Hume, Traktat o naturze ludzkiej, t. I, PWN, Warszawa 1963, s. $118-127$.
} 
zostało negatywne rozwiązanie kwestii, zwanej przez Poppera „logicznym problemem indukcji". Hume wychodzi od stwierdzenia (bodaj najsłynniejszego), że niemożliwe jest uzyskanie wiedzy o oddziaływaniu przyczynowo-skutkowym z samej obserwacji. Skoro zaś nie można stwierdzić z pewnością, że jakiś fakt musi skutkować innym, zatem wszelkie wyjaśnianie obecnych doświadczeń za pomocą minionych faktów nie ma mocy dedukcyjnej. Stąd Hume stwierdza:

(...) nawet wówczas, gdy doświadczenie już nas poinformuje o ich [przyczyn i skutków] stałym powiązaniu, nie możemy pojąć naszym rozumem, dlaczego można by rozciągnąć to doświadczenie poza te poszczególne przypadki, które były przedmiotem naszej obserwacji ${ }^{6}$.

Podobne nieporozumienia wynikają z założenia podobieństwa obserwowanych faktów, którego z punktu widzenia logiki nie da się uprawomocnić. Stąd wysnuwanie wniosków z określonych przeszłych przypadków zależności o występowaniu stałych prawidłowości, nie jest dziełem rozumu. ,[C]zynią to jakieś zasady, które wiążą idee tych rzeczy i łączą je w jedno w wyobraźni" 7 , która zawłaszcza sobie szersze obszary, niż przysługują rozumowi. Wyciągając wnioski, niejako podszywa się pod uczestnika sfery racjonalnej, gdyż reguł wiązania ze sobą różnych idei, przez wzgląd na dostrzeżone podobieństwo, styczność i następstwo, w żadnym razie nie cechuje nieomylność. Hume'owski sceptycyzm w tym punkcie można ująć następująco: nie sposób wnioskować z przypadków przeszłych o przyszłych. Określenie wyprowadzanych wniosków mianem prawdopodobnych (w miejsce: „prawdziwych”) niczego tu nie zmieni.

W związku z tak radykalnym postawieniem sprawy, trudno się dziwić, że, jak pisze uczeń Poppera, John Watkins: „odpowiadanie Hume'owi urosło do rozmiarów przemysłu filozoficznego" 8 .

\footnotetext{
${ }^{6}$ Tamże, s. 124.

${ }^{7}$ Tamże, s. 125 .

${ }^{8}$ Tamże, t. I, dz.cyt, s. XII.
} 
Demaskacja indukcjonizmu (czyli tak zwany skandal indukcji) może okazać się wręcz wstrząsająca, przynajmniej po dogłębnym przemyśleniu praktycznych konsekwencji jej poważnego potraktowania. Tych przejętych zapewne najbardziej irytuje Popperowskie spuszczanie powietrza z balonika, czyli inaczej mówiąc: demaskacja demaskacji. Można powiedzieć, że (wbrew deklaracjom) dla Poppera problem indukcji wydaje się nie istnieć. Występuje jedynie pewne indukcyjne nieporozumienie.

Przechodząc do meritum sprawy: Popper zgadza się z Hume'em, że przyszłość faktycznie nie musi być taka, jak przeszłość, zatem wnioskowanie z przeszłości o przyszłości jest zasadniczo nieuzasadnione; w szczególności - wyciąganie wniosków z dotychczas przeprowadzonych testów o przyszłym zachowaniu teorii. Odpowiedź na pytanie, czy przyszłość będzie podobna do przeszłości, w swej autobiografii Popper streścił w jednym zdaniu: „przyszłość po części będzie podobna do przeszłości, a po części nie będzie podobna do przeszłości" ${ }^{9}$, czym dowiódł co najwyżej, że całkowicie rozminął się z Hume'owskim problemem. Jednak czytając jego główne dzieła, Logike odkrycia naukowego i Wiedze obiektywna, już nie można odmówić mu zmierzenia się, mniej czy bardziej udanego, z sednem właściwego zagadnienia.

Popper przyznaje, że nauka nie opiera się na wnioskowaniu z przypadków przeszłych o nieznanych ${ }^{10}$, co jednak, jego zdaniem, nie oznacza, że poznanie naukowe jest niemożliwe. Prawomocność gwarantuje metoda hipotetyczno-dedukcyjna, dzięki procedurom koroborowania i nieustannej możliwości obalenia. Stopień potwierdzenia nie daje żadnej gwarancji, że skoroborowana w surowych testach teoria nie zostanie za chwilę sfalsyfikowana, gdyż koroboracja rzeczywiście nie mówi nic o przyszłości.

Dlaczego zatem Popper określa teorię mianem nie tylko „tymczasowego domniemania”, a wręcz „zbioru oczekiwań”? Z pewnością nie są to przypuszczenia prawomocne w sensie logicznym.

\footnotetext{
${ }^{9}$ K.R. Popper, Nieustanne poszukiwania. ., dz. cyt., s. 202.

${ }^{10}$ Por. K.R. Popper, Wiedza obiektywna. Ewolucyjna teoria epistemologiczna, PWN, Warszawa 1992, s. 10 nn.
} 
Jednak odpowiadając na jeden z pragmatycznych problemów indukcji ( „Którą teorię - z racjonalnego punktu widzenia - winniśmy preferować w działaniu praktycznym?" ${ }^{11}$ ), Popper jako przesłankę podaje właśnie ów „niemówiący nic o przyszłości” stopień koroboracji. Nasuwa się banalne pytanie: skoro nic nie świadczy o tym, że teoria dobrze skoroborowana będzie lepiej sprawować się w przyszłości niż mniej potwierdzona, a nawet, na przykład, sfalsyfikowana, dlaczego jej wybór miałby okazać się szczególnie praktyczny? Odpowiedź Poppera nie zaskakuje: „nie ma dobrych powodów, aby się spodziewać, że w praktyce będzie to wybór właściwy"12. Tymczasem działanie praktyczne podejmuje się rzecz jasna ze względu na jego rezultaty.

Popper argumentuje, że choć naukowiec spodziewa się niezmienności po formułowanych przezeń prawach, to jednak takie oczekiwanie nie wynika z realnie odkrytej w świecie cechy, a już na pewno nie opiera się na niezawodności procedury koroborowania, lecz jest kwestią przyjętego systemu pojęciowego: stałe regularności określamy mianem „praw”. Dalej wyjaśnia:

(...) aczkolwiek wiedza o istnieniu prawdziwych praw zwiększyłaby prawomocność poszukiwania tych praw, to poszukiwanie jest usprawiedliwione - nawet mimo braku tej wiedzy - naszą ciekawością i samą tylko nadzieją na powodzenie $^{13}$.

Zatem nie musimy udawać, że wiemy coś, czego nie wiemy, by nadać znamiona prawomocności niezmiernie dla nas ważnej grze, gdyż owa gra da się usprawiedliwić w inny sposób, poprzez uzasadnioną (a w tej sytuacji konieczną) nadzieję.

Jeszcze raz wróćmy do podstawowego problemu: dlaczego przyjmować skoroborowane hipotezy, przy utrzymaniu w mocy Hume'owskiego rozstrzygnięcia? W wersji kolokwialnej odpowiedź

${ }^{11}$ Tamże, s. 34 .

${ }^{12}$ Tamże, s. 35.

${ }^{13}$ K.R. Popper, Logika odkrycia naukowego, PWN, wyd. II, Warszawa 2002, S. 451 . 
Poppera można streścić: „a dlaczego nie?”. Popper psychologiczny problem indukcji - „(.. ) skąd biorą się w nas oczekiwania, w które pokładamy wielką ufność?"14 - uznaje najzupełniej błahym: zaufanie z definicji cechuje irracjonalność, co nie zmienia faktu, że (szczególnie w tym przypadku) jest istotne w działaniu praktycznym. Kto nie widzi racji za tym, że jego lodówka ochłodzi, a nie spożyje włożone doń jedzenie, ten w rzeczy samej ma problem, lecz bynajmniej nie o charakterze metodologiczno-metafizycznym ${ }^{15}$.

$\mathrm{Na}$ gruncie wyznaczonym przez problem logiczny, wiara w sprawdzone teorie pozostaje irracjonalna. Cała koncepcja, zanim wprowadzony zostanie kontrowersyjny pomysł o asymptotycznym zbliżaniu się do prawdy, wydaje się sprowadzalna do praktycznych wskazówek odnośnie subiektywnego podejścia do poznawania świata przez samego naukowca. Warto mieć nadzieję, że sprawdzona teoria to lepsza teoria, a raczej: trzeba działać tak, jakby „skoroborowana” oznaczało „lepsza”, bo to jedyna szansa na poznanie świata.

Sformułujmy ostatecznie Popperowską odpowiedź udzieloną Hume'owi. Mianowicie, nauka musi rozwijać się przez formułowanie śmiałych teorii i dedukcje przewidywań, a nie - metodą indukcyjną, by móc zasłużyć na zaszczytne miano „wiedzy”. Dlaczego zatem Imre Lakatos, węgierski filozof a zarazem krytyczny kontynuator myśli Poppera, apeluje do niego „o powiew «indukcjonizmu»"16? W opozycji do zarzutów stawianych przez takich filozofów, jak John Watkins, Lakatos nie twierdzi, że Popperowska metodologia w swych zakamarkach kryje całkiem potężny ładunek indukcyjny. Wręcz przeciwnie, zaopatrzenie się w takowy byłoby, jego zdaniem, krokiem naprzód, a nie wstecz, względem negatywnych rozstrzygnięć Hume'a.

\footnotetext{
${ }^{14}$ K.R. Popper, Wiedza obiektywna..., dz. cyt., s. 12.

${ }^{15}$ „«Czemu sądzisz, że gorąca płyta kuchenna sparzy Cię?» - Czy masz ku temu jakieś racje? I czy racji tu potrzebujesz?". L. Wittgenstein, Dociekania filozoficzne, PWN, Warszawa 2008, §476.

${ }^{16}$ Zob. I. Lakatos, Pisma z filozofii nauk empirycznych, PWN, Warszawa 1995 , s. $269-284$.
} 
Lakatos określa koncepcję zawartą w Logice odkrycia naukowego mianem „sceptycyzmu połączonego z pochwała gry naukowej”" ${ }^{17}$. Tym i niczym więcej musi być każda teoria dokonywania racjonalnych wyborów pomiędzy systemami, w przypadku uznania, że nigdy nie można stwierdzić, które z nich są faktycznie bliższe prawdzie. Wszak w żadnym razie nie stanowi przezwyciężenia sceptycyzmu stwierdzenie, że bezmiar naszej niewiedzy w odniesieniu do poszczególnych obszarów świata cechować może rozmaity stopień niepewności. Zdaniem Lakatosa, Popperowski pogląd, jakoby nasza wiedza mogła się rozwijać, gdy my o tym nie wiemy, jest sprowadzalny do postaci: „nigdy nie mogę wiedzieć, że wiadomo, iż X” i znaczy tyle samo, co: „nigdy nie moge wiedzieć, że X". W ten sposób dochodzimy do klasycznej postaci akademickiego sceptycyzmu. Niewątpliwie przyjęcie, iż „wiadomo, że X", podczas gdy nie ma nikogo, kto by o tym wiedział, nie uczyni z popperysty antysceptyka.

Lakatos postuluje ponowne połączenie problemu demarkacji i zagadnienia indukcji. Zauważa, że o ile Popperowskie traktowanie nauki jako gry, której reguły po prostu się konstatuje (stosując się doń, by uniknąć wykluczenia), pozwala na sformułowanie kryterium preferencji hipotez, o tyle patrząc na tę sytuację niejako z zewnątrz, z szerszej, epistemologicznej perspektywy, takie wybory wymagają uzasadnienia. Innymi słowy, Popper odgranicza naukę od pseudonauki przez podanie wzorca racji dla wyboru „lepszych" hipotez. By te ostatnie były lepsze w sensie obiektywnym, a nie tylko w odniesieniu do kanonów naukowości, należy wskazać, dlaczego w ogóle powinno się preferować wyjaśnienia naukowe, w miejsce na przykład magicznych czy zdroworozsądkowych (,zapewne Słońce kręci się wokół Ziemi, skoro każdy może zaobserwować ten fakt gołym okiem"). W ramach gry, którą zwiemy nauką, hipotezy poddaje się eksperymentom, by móc przypisywać większą wartość, przynajmniej na zasadzie nadziei, tym, które przeszły surowe testy, niż teoriom obalonym tudzież niete-

${ }^{17}$ Tamże, s. 270. 
stowalnym (choćby nawet z przyczyn technicznych); to, według Lakatosa, nie budzi kontrowersji. Żeby jednak móc preferować metanaukowe zasady na przykład od reguły: „wybieraj tę hipotezę, którą wymyśliłeś podczas pełni księżyca", w tym celu owa praktyka musi mieć jakieś odniesienie do prawdy, które z kolei zagwarantować miała kategoria prawdoupodobnienia. To jest ten moment, który węgierski metodolog sugeruje doprawić indukcjonizmem. Bez tego czynnika, jego zdaniem, nie można mówić o związku między koroboracją a prawdoupodobnieniem. W przeciwnym razie pozostaniemy w położeniu sceptyka; być może nawet pełnego nadziei sceptyka, ale zarazem mającego równie mało racji przemawiających na rzecz nauki, jak sceptyk będący skrajnym pesymistą. Zaś bez silnych argumentów na rzecz zbliżania się nauki do prawdy nie sposób krytykować praktyk pseudonaukowych chyba już tylko personalnie lub za pomocą kryteriów estetycznych.

Atoli zdaniem Latakosa to nie piękno, a indukcja miałaby zbawić Poppera od sceptycyzmu. Pozostaje proste pytanie: skoro zarówno kryterium estetyczne, jak i zasada indukcji, są niemożliwe do uprawomocnienia, w czym lepsze jest drugie z nich? W pierwszym przypadku, w miejsce obiektywnego poznania, mamy przynajmniej gwarancje przyjemnego subiektywnego doznania, co nie pozostaje całkowicie bez znaczenia, w przerażająco niepoznawalnym świecie, którym rządzi chaos. Zdaniem Lakatosa, hipotetyczność zasady indukcji usprawiedliwia jej przyjęcie tak samo, jak wywrotność zdań bazowych, czy teorii. Tymczasem Popper chętnie zgadza się na uczynienie miejsca dla pewnej dawki metafizyki, może nawet niezbędnej dla rozwoju nauki, krytykowalnej, a zatem w rzeczy samej hipotetycznej. Lakatosa zasada indukcji, w przeciwieństwie do indukcyjnych postulatów empirystów z Koła Wiedeńskiego, ma być zasadą metafizyczną. Taka metafizyka wydaje się jednak co najwyżej warunkiem koniecznym, lecz nie wystarczającym dla właściwego indukcjonizmu - a dopiero ten pozwala przedłożyć praktykę naukową nad irracjonalną. Jakkolwiek kuriozalne się to może wydać, zdaniem Lakatosa najpierw stwierdzamy, że nauka jest takim poznaniem, które rozwija się przez 
indukcje, potem uprawomocniamy ten fakt za pomoca zasady indukcji, a na koniec stwierdzamy, że nauka jest lepszą praktyką poznawczą, właśnie dlatego, że rozwija się przez indukcję.

Jak widać, całość Lakatosowego rozumowania wychodzi, wbrew rozstrzygnięciom Hume'a, z założenia o wartościowości indukcji. Skrajny sceptyk, astrolog, antydarwinowski kreacjonista czy jakikolwiek inny „pozaracjonalista”, patrzący rzeczywiście z zewnątrz na naukową grę, nie myśli o sobie: „mogę być co najwyżej pseudonaukowcem, gdyż nie znajduję się po właściwej, empiryczno-indukcyjnej stronie barykady”. Sądzi raczej: „,skoro indukcja jest metodą nieuprawnioną, zatem nauka jest nieprawomocna"; zatem można dalej spokojnie wróżyć z ręki. Wydaje się, że w takim wypadku jedyną możliwą polemiką jest Popperowskie (lub jakiekolwiek inne) unaocznienie, że nauka nie jest indukcyjna, więc żeby wykazać jej nieprawomocność, trzeba by było pójść o krok dalej, niż odważył się Hume - spaść z pozornej przepaści w prawdziwą. Takim krokiem może się niewątpliwie wydać Popperowskie odrzucenie programów badawczych, których celem było stworzenie tak zwanej logiki indukcji - w imię bezsensowności podejmowania podobnych wysiłków.

\section{Popper a Carnap, czyli o kryptoindukcjonizmie}

Głównym celem, jaki przyświecał Popperowi podczas pisania Logiki odkrycia naukowego, nie była polemika ze skrajnym sceptycyzmem Davida Hume'a, którego sława już wtedy zdawała się przewyższać faktyczne oddziaływanie głoszonych przezeń poglądów. Nieskrywanym dążeniem Poppera było wykazanie błędów w pogląach aktualnie głoszonych przez, w rzeczy samej wpływowych, przedstawicieli Koła Wiedeńskiego. Jak pisze Imre Lakatos (do którego zdania ów Carnapowski oponent z pewnością odniósłby się przychylnie): „(...) w tej kampanii Popper odniósł zdecydowane zwycięstwo" ${ }^{18}$.

\footnotetext{
${ }^{18}$ I. Lakatos, Pisma z filozofii nauk empirycznych, dz. cyt., s. 274-275.
} 
Carnap głosił (po 1936 roku i porzuceniu programu weryfikacjonistycznego), że prawa nauki, stanowiące hipotezy o rzeczywistości, są potwierdzane jednostkowymi faktami. Wraz z liczbą pozytywnie zakończonych testów rośnie stopień konfirmacji prawa. Tak oto, na podstawie faktów empirycznych, dokonywana jest indukcyjna ocena hipotez naukowych. O stopniu konfirmacji orzeka się, porównując ze sobą zdania (to zgadza się z Popperowskim poglądem): jedno udziela $\mathrm{w}$ jakiejś mierze potwierdzenia innemu, co można ująć w kategoriach rachunku prawdopodobieństwa (a to się drastycznie z myślą Poppera rozmija). Teorii przypisywane jest prawdopodobieństwo, w związku z czym określa się stopień konfirmacji, stanowiący dlań uzasadnienie. Już widać pierwszą podstawową asymetrię względem koroboracji, która stanowi jedynie raport z przeszłych testów. Przy wszystkich ewidentnych różnicach, analogie do Poppera są równie oczywiste. Przykładowo Carnap pisze:

Nie możemy zweryfikować prawa, ale możemy je sprawdzać, sprawdzając poszczególne jego przypadki, tj. zdania szczegółowe, które wyprowadzamy z prawa i z innych zdań uprzednio uzasadnionych. Jeśli w toku kolejnych zabiegów sprawdzających nie natrafimy na przypadek negatywny, a liczba stwierdzonych przypadków pozytywnych rośnie, to rośnie też stopniowo nasza wiara w trafność sprawdzanego prawa $^{19}$.

Owe słowa równie dobrze mogłyby zostać wypowiedziane przez Poppera, który także uznawał sprawdzalność przez predykcje, niemożliwość weryfikowalności, konieczność uznawania wiedzy zastanej i „wiarę w trafność", a nie ostateczne uzasadnienie, jako efekt pozytywnie zakończonego eksperymentu. Jest jedna zasadnicza rozbieżność: Carnap, chcąc przypisywać prawdopodobieństwo teoriom, szuka dalszych racji dla testowania, a nie, jak Popper, konstatuje fakt praktyki naukowej.

\footnotetext{
${ }^{19}$ R. Carnap, Filozofia jako analiza jezyka nauki, PWN, Warszawa 1999, s. 75 .
} 
Choć Popperowska teoria metody hipotetyczno-dedukcyjnej miała za zadanie ostatecznie wyrugować indukcjonizm, głównie ten w wydaniu Koła Wiedeńskiego, to jedna z odmian popularnego zarzutu głosi, że koncepcja przybliżania się do prawdy tylnymi drzwiami ponownie wpuściła to, co oficjalnie zwalczała, gdyż sama koncepcja koroboracji, bez prawdoupodobnienia, okazuje się okrojoną z narzędzi probabilistycznych metodologią logicznych empirystów, ze szczególnym uwzględnieniem głównych propagatorów teorii konfirmacji: Hansa Reichenbacha i Rudolfa Carnapa. Rzekomo koncepcja koroboracji nie wnosi niczego, o czym nie pisałby Carnap, jeśli nie liczyć krytyki przypisywania pozytywnego znaczenia wysokiemu prawdopodobieństwu. W praktyce indukcyjne potwierdzanie i koroborowanie miałyby wyglądać tak samo - w każdym przypadku to tylko szereg mniej lub bardziej krytycznych testów, niezależnie od tego, jakim określeniem ów proces opiszemy. Rzeczywiście wydaje się, że poglądy Carnapa i Poppera w kwestii kryterium preferencji hipotez nie różnią się tak diametralnie, jak tego życzył sobie ten ostatni. Ich metodologie, odpowiadając na inne pytania, dają całkiem podobne odpowiedzi (a nie: ukazują różne rozwiązania tego samego problemu).

Jeśli obydwie metodologie, Carnapa i Poppera, zinterpretujemy jako wykład warunków możliwości racjonalności nauki, która to racjonalność jest faktem, wówczas podobieństwo opozycyjnych koncepcji konfirmacji i koroboracji może okazać się znacznie mniej problematyczne. Wykraczając poza idee głoszone przez Carnapa, Popper jedynie zapytuje dodatkowo: w jakich pojęciach należy ująć opis praktyki naukowej, żeby uwidocznić, iż nie jest ona irracjonalna? Z kolei Carnap, szukając racji dla praktyki naukowej, pyta, dlaczego sensownie jest przyjmować testowane teorie, a robi to, próbując przypisać prawdopodobieństwo hipotezom, co sensowne, zdaniem Poppera, okazać się nie może. Starania Carnapa skazane są na porażkę niejako w punkcie wyjścia, gdy dokonuje próby opisu praktyki naukowej jako indukcyjnej ${ }^{20}$.

${ }^{20}$ Zob. I. Lakatos, Pisma z filozofii nauk empirycznych, dz. cyt., s. 276. 
Czy koroborowanie może być w praktyce rzeczywiście tym samym, co Carnapowskie konfirmowanie? Popper nie może twierdzić, że naukowiec ostatecznie koroboruje, a nigdy konfirmuje teorię w testach. Zresztą jak osoba trzecia miałaby odróżnić test zmierzający do obalenia od testu dążącego do potwierdzenia? Wydaje się, że różnica może tkwić jedynie w nastawieniu naukowca. To znany, powracający z różnych stron zarzut o kryptoindukcjonizm Poppera. W kontekście koncepcji Carnapowskiej, można go streścić w zdaniu: koroboracja to nic innego, jak konfirmacja pozbawiona narzędzi probabilistycznych; jest po prostu indukcyjnym potwierdzaniem teorii przez wielokrotne nieudane próby obalenia. Jakie inne racje pozwalają uznać teorię skoroborowaną za lepszą? Inaczej mówiąc, dlaczego należy przyjąć lepiej sprawdzone hipotezy?

Próbując odpowiedzieć na te pytania, zauważmy najpierw, że podczas gdy w filozofii Kanta punkt wyjścia stanowiła pewność, towarzysząca nauce, to dla Poppera istotniejsza okazała się racjonalność praktyki naukowej; ten fakt Popper usiłuje wyjaśnić. Nie pyta o prawomocność nauki, lecz jak jest możliwa i co jest nauką, a szerzej: co jest racjonalne. Postęp wiedzy empirycznej rzeczywiście ma miejsce; faktem jest, że nauka zbliża się do prawdy, a więc uzasadnioną jest nadzieja, że na ogół poszczególne teorie też zbliżają się do prawdy. Jednak w konkretnych przypadkach nie potrafimy ich jednoznacznie wyróżnić. Jak zatem odnieść racjonalność całej praktyki naukowej do racjonalności aktu preferencji konkretnej teorii? Do tego właśnie miała służyć kategoria prawdoupodobnienia: co jest celem całej nauki (dostarczenie możliwie pełnego obrazu świata), ma być ideałem dla poszczególnych teorii (jak największa zawartość prawdziwa). Można by powiedzieć, że naukowiec ma nadzieję na prawdoupodobnienie konkretnej teorii wynikające ze skoroborowania, ze względu na fakt przybliżania się do prawdy całej nauki, w wyniku praktyki surowego testowania. Zatem miast zastanawiać się, jak koroborowanie teorii ma uprawomocniać naukę, można wyjść od faktu nauki i przełożyć 
jej racjonalność na „prawomocność” nadziei, wyrosłej na żyznym gruncie raportów z przeszłych testów.

W podobnym duchu ,godzenia” prezentowanych koncepcji, przedstawił swój koncept Evaldas Nekrašas. Zaproponował rozdział: metodologia Carnapa lepiej przystaje do nauk stosowanych, jak medycyna czy psychologia (jakkolwiek nazwanie tej ostatniej nauką w sensie science wciąż może budzić spore kontrowersje), zaś koncepcja Popperowska do nauk teoretycznych (przede wszystkim chodzi o fizykę i wielkie rewolucje naukowe, jak w przypadku przejścia od fizyki Newtona do Einsteina) ${ }^{21}$. W pewnym sensie sam Popper sugeruje podobne rozwiązanie, pisząc niejednokrotnie, że podczas gdy on postuluje preferowanie hipotez śmiałych, wysoce obalalnych, a więc tych o wysokiej zawartości informacyjnej (obejmujących wiele faktów), to tymczasem probabiliści pokroju Rudolfa Carnapa „sympatyzują" raczej z teoriami ostrożnymi, trudniej falsyfikowalnymi, o wąskim zasięgu ${ }^{22}$. Metodologia Carnapa w tym ujęciu odnosiłaby się do innego rodzaju teorii, ponieważ indukcja nie może stanowić narzędzia rewolucji naukowych. Jak sugeruje Nekrašas, w pewnym sensie jest to poważne, a wręcz dosłowne potraktowanie krytyki Thomasa Kuhna, skierowanej w stronę Poppera, głoszącej, jakoby ten ostatni był „permanentnym rewolucjonistą". Tymczasem nie traktujemy tych słów jako oskarżenia, gdy uznajemy, że właśnie te rewolucje w pierwszej kolejności Popper opisywał.

${ }^{21}$ Zob. E. Nekrašas, Wiedza prawdopodobna, PWN, Warszawa 1992, s. $207-208$.

${ }^{22} \mathrm{~W}$ tym miejscu może pojawić się zarzut, iż testowanie hipotez w naukach stosowanych de facto pociąga za sobą całe zaplecze teoretyczne, a więc wiąże się tymi samymi problemami (z prawdą, realizmem i nieuprawnionym stosowaniem indukcji), z którymi musi zmagać się metodologia Poppera. Nie wydaje się on jednak trafiony: jeśli sprawdza się hipotezy o naprawdę wąskim zasięgu, zakres background knowledge, towarzyszącej każdej z nich, okazuje się w wystarczającym przybliżeniu jednakowy. Problemy nauk stosowanych nie wywołują bezpośrednio rewolucji w naukach teoretycznych (chyba tylko na zasadzie „efektu motyla”). 
Istnieje również praktyczny argument na rzecz rozdziału metodologii, kierującego Poppera do nauk teoretycznych, ze szczególnym wskazaniem wielkich rewolucji naukowych, a Carnapa do nauk stosowanych, w tym techniki. Za punkt wyjścia krytyki przyjmuje się tym razem realia praktyki testowania. Wybitni naukowcy, którzy mogą wykazać się znacznymi sukcesami, dysponują czasem, pieniędzmi i laboratorium, w którym poddają swoje teorie najwymyślniejszym procedurom. Tymczasem jak wyglądałaby wersja metodologii przeznaczona na przykład dla inżynierów budujących mosty? Jak pisze John Watkins, w działaniu praktycznym, którego skutki, w przypadku błędu, mogłyby być tragiczne, wskazane jest stosowanie hipotez najbezpieczniejszych, wręcz takich, co do których wątpliwości już się nie pojawiają. Nie wydaje się, by radość ze sfalsyfikowania hipotezy mogła przyćmić żal spowodowany stratami w ludziach, nawet w przypadku najzagorzalszych zwolenników krytycznego racjonalizmu.

Irena Szumilewicz-Lachman ${ }^{23}$ wskazuje na jeszcze jeden praktyczny aspekt: skażenia środowiska. W naukach stosowanych nie każdy wynik eksperymentu jest wart skutków, które przynosi; na przykład konieczności pozbycia się dużej ilości toksycznego „leku”, gdy hipoteza o jego skuteczności zostanie ostatecznie sfalsyfikowana; nie mówiąc już o przechowywaniu tego specyfiku, ze względu na niemożliwość jednoznacznego stwierdzenia, że baza nigdy nie zmieni się na tyle, iż dana teza na nowo zostanie przywrócona do łask.

Tak oto została udzielona odpowiedź na pytanie, co jest racjonalne w testowaniu hipotez o małym zasiegu, a co w przypadku wymieniania całych systemów na nowe. Można zarzucić, że sugestia, jakoby koncepcje koroboracji i konfirmacji nie różniły się specjalnie od siebie, a więc odpowiedzi owych dwóch filozofów były w zasadzie takie same, pojawiła się równolegle do stwierdzenia, jakoby Carnap i Popper odpowiadali na różne pytania (o metodę nauk stosowanych i teoretycznych), a wówczas nie byłoby sensu zestawiać tych rozwiązań. A w istocie o to by właśnie chodziło:

${ }^{23}$ Zob. J. Watkins, Nauka a sceptycyzm, dz. cyt., s. XXI. 
w naukach stosowanych korzysta się zasadniczo z uzasadnień innego typu niż w sytuacji, gdy chce się zrewolucjonizować obraz świata, dlatego być może opis indukcyjny nadaje się w tym pierwszym przypadku lepiej. Nie jest to jednak różnica zerojedynkowa, jak tego życzyłby sobie Popper. Chodzi jedynie o inne rozłożenie akcentów.

Zatem co nowego pojawia się u Poppera, w odróżnieniu od Carnapa? To, że Popper nie uważa, jakoby nauka wymagała uprawomocnienia, a pyta: kiedy naukowiec postępuje racjonalnie, ze względu na fakt praktyki naukowej jako ideału racjonalności. Teoria nie jest racjonalnie przyjmowalna, bo jest prawdoupodobniona czy prawdopodobna w związku z pomyślnymi rezultatami testów. To naukowiec jest racjonalny, bo daną teorię testuje. A czy jest indukcjonistą, czy popperystą, to oczywiście w samej praktyce sprawdzania niczego nie zmienia. W tym i tylko tym sensie koroboracja to „indukcja w przebraniu”, Popper jest kryptoindukcjonistą, a Carnap kryptopopperystą ${ }^{24}$.

\section{Popper a Watkins, czyli o neopopperyzmie}

„Szczypta indukcjonizmu”, sugerowana przez Lakatosa, w celu umożliwienia przejścia od koroboracji do prawdoupodobnienia, zdaniem innego komentatora, Johna Watkinsa, jest już w tym miejscu pełnowymiarowo obecna, czego bynajmniej nie należy uważać za zaletę Popperowskiej metodologii. Watkins wskazuje momenty, w których, jego zdaniem, Popper zbliża się do teorii indukcyjnych, oraz podaje strategie eliminacji owych, między

\footnotetext{
${ }^{24}$ Por. E. Nekrašas, Wiedza prawdopodobna, dz. cyt., s. 210. Ów wniosek jest o tyle niekontrowersyjny, że Popper zdaje się odmawiać naukom stosowanym miana „naukowości”, zatem ich metodologia znajduje się niejako poza zakresem oddziaływania jego koncepcji. Jednakowoż należy zauważyć, że prezentowane „pogodzenie” poglądów Carnapa i Poppera wymagałoby jeszcze jednego znacznego ustępstwa ze strony indukcjonistycznej, a mianowicie rezygnacji z narzędzi probabilistycznych, dopóki służą one usprawiedliwieniu preferencji hipotez, gdyż z punktu widzenia Poppera byłby to wciąż zbędny naddatek.
} 
innymi przez pozbycie się kategorii prawdoupodobnienia. Swoją koncepcje, czyli zreformowany krytyczny falsyfikacjonizm, sam określa mianem „neopopperyzmu”.

Krytykujac koncepcję verisimilitude ${ }^{25}$, Watkins wychodzi od postawienia dychotomii: albo uwierzymy w racjonalność naukową, albo pogrążymy się w mrokach sceptycyzmu. Stawia sobie za cel sprawdzenie, czy Popperowi rzeczywiście udało się odpowiedzieć na Hume'owskie odrzucenie naukowej racjonalności, przy utrzymaniu zanegowania prawomocności wprowadzania kategorii prawdopodobieństwa (czyli, w wersji współczesnej, konstruowania logiki indukcji). Watkins określa racjonalność w nauce jako możliwość sformułowania „w wystarczająco wielu przypadkach” kryterium preferencji między teoriami i zgadza się z Popperem, że punktem wyjścia musi być po prostu koroborowanie. Dlaczego jednak przeszłe testy miałyby stanowić o wartości teorii?

Rozważmy sytuację, w której: $V s(a 2)>V s(a 1)$ i $C o(a 2)>$ $C o(a 1)$, gdzie $C o(x)$ to stopień skoroborowania teorii $x$, a $V s(x)$ to stopień jej prawdoupodobnienia. Czy z samego $C o(a 2)>C o(a 1)$ można wyciągnąć wniosek, że $V s(a 2)>V s(a 1)$ ? Popper twierdził, że co prawda nie dysponujemy racjami w sensie logicznym, to jednak możemy się tego domyślać ${ }^{26}$. Watkins tymczasem uznaje podobne deklaracje za mylące. Jego zdaniem, Popper tak naprawdę bliższy byłby stwierdzeniu, że dysponujemy dobrymi powodami, by wiązać koroborację z prawdoupodobnieniem; jakąś słabszą odmianą logicznych racji, cokolwiek by to miało znaczyć. Popperowski krytyk za Lakatosem zauważa, że jedyny możliwy pomost $\mathrm{w}$ sensie logicznym między potwierdzeniem a przybliżaniem do prawdy stanowi nic innego, jak zasada indukcji. Skoro Popperowi wystarczają quasi-racje - owe wskazówki, powody czy argumenty - można oczywiście się zgodzić, że i wersja indukcjonizmu jest osłabiona. To właśnie Watkins określa mianem wpuszczania tylnymi drzwiami tego, co zostało wyrzucone główną bramą.

${ }^{25}$ Zob. J. Watkins, Nauka a sceptycyzm, dz. cyt., s. 222-268.

${ }^{26}$ Zob. K.R. Popper, Wiedza obiektywna..., dz. cyt., s. 472. 
Do przedstawienia sedna Watkinsowego zarzutu konieczne jest dodatkowo wprowadzenie pojęcia ,niezgodnych odpowiedników" ${ }^{27}$, czyli takich teorii, których klasy konsekwencji pozostają ze sobą w relacji jedno-jednoznacznej. Inaczej mówiąc, klasy odpowiadają sobie nawzajem, gdy dla każdej konsekwencji jednej teorii można znaleźć odpowiednik wśród konsekwencji wynikających z drugiej, niekoniecznie zgodny. Dzięki temu pojęciu, istnieje prosty sposób przedstawienia, iż nie można wnioskować o przybliżeniu do prawdy danej hipotezy z surowości testów, które przeszła (stopnia koroboracji), interpretując zależność $V s(a 1)>V s(a 2)$ w ten sposób, że najczęściej odpowiednik prawdziwej konsekwencji $a 1$ wśród konsekwencji $a 2$ ma być fałszywy. Krytykę Poppera przez Watkinsa w tym punkcie można w skrócie przedstawić następująco: skoro o tym, że teoria przejdzie kolejne testy, nie można wnioskować (choćby tylko z pewnym prawdopodobieństwem) ani z faktu, że już jakieś przeszła, ani ze stopnia bliskości do prawdy, zatem nie jest uprawnione domyślanie się stopnia prawdoupodobnienia ze skoroborowania. $\mathrm{W}$ przeciwnym razie doszłoby do sytuacji, w której informacje o przeszłych stanach świata pozwalają, wbrew negatywnym rozstrzygnięciom Hume'a, wnioskować o przypadkach niezaobserwowanych.

Watkins poddaje krytyce jeszcze jeden istotny punkt koncepcji prawdoupodobnienia. Skoro nie jest możliwe podanie racji na rzecz przybliżania się do prawdy hipotezy skoroborowanej i jesteśmy zmuszeni opierać się na własnych (choćby nie indywidualnych, lecz zbiorowych) domysłach, zachowanie racjonalnego oddźwięku koncepcji wymagałoby podania kryteriów kontroli; by przypisywanie prawdoupodobnienia nie miało charakteru dowolnego, opartego na subiektywnym poczuciu. Watkins twierdzi jednak, że podstawowy zarzut wobec twierdzenia, iż $V s(a 1)>V s(a 2)$, opiera się na stwierdzeniu nieporównywalności zawartości teorii $a 1$ i $a 2$. Jednakowoż częste wysuwanie takiego zarzutu - a usilna krytyka to jeden z postulatów szeroko pojętej Popperowskiej racjo-

${ }^{27}$ Zob. J. Watkins, Nauka a sceptycyzm, dz. cyt., s. 93-127. 
nalności - nie tyle podważa faktyczne przybliżanie się do prawdy danych hipotez, co samą koncepcję prawdoupodobnienia, której fundamentalnym założeniem jest porównywalność konkurencyjnych teorii. Ostatecznie więc okazywałoby się, że przybliżanie się do prawdy nie jest celem nauki. Skoro nie mamy obiektywnego kryterium podejmowania decyzji, nie możemy przypuszczać, że doprowadzą nas one do celu. Zdaniem Watkinsa, pozorną racjonalność Popperowskiego poznania naukowego czeka powrót do punktu wyjścia wyznaczonego przez lęki sceptycyzmu.

Zarzuty podobne do Watkinsowych formułuje polski filozof nauki, Adam Chmielewski ${ }^{28}$. Sugeruje, iż Popperowsko-Hume'owska krytyka indukcji prowadzi do wnioskowania z powtarzanego doświadczenia o wartości hipotezy, na podstawie czego nie sposób zabronić snucia przypuszczeń o przyszłym zachowaniu teorii w testach. Czym innym może być wartość hipotezy, określona jako jej „bliskość wobec prawdy”, jak nie nadzieją na przyszłość? Rzecz jasna, taki wniosek ma już charakter stricte antypopperowski. Zatem wydawałoby się, że wbrew deklaracjom Popperowi nie udało się uciec od podstawowej indukcyjnej pomyłki. Zdaniem Chmielewskiego, jedyny ratunek dla tej metodologii stanowiłby instrumentalizm ${ }^{29}$.

Nim przystaniemy na tak drastyczne konkluzje, które mogłyby wyrwać z grobowego snu zarówno Hume'a, jak i Poppera, warto przyjrzeć się raz jeszcze wnioskom samego Watkinsa. Podczas gdy niemożliwość wnioskowania ze stopnia skoroborowania o dalszych losach teorii nie budzi wątpliwości, to już wnioskowanie o przyszłości z prawdoupodobnienia nie musi być tak oczywiste, jak się to uczniowi Poppera wydaje. Sprawa jest niezmiernie prosta. Ponieważ pierwsze przejście (od koroboracji do przyszłości), a raczej jego brak, ma charakter logiczny, zatem nie sposób zestawiać go z drugim (od prawdoupodobnienia do przyszłości),

\footnotetext{
${ }^{28}$ Zob. A. Chmielewski, Filozofia Poppera..., dz. cyt., s. 72 n.

${ }^{29}$ Jak pisze Władysław Krajewski: „Proponowanie tego filozofowi, który całe życie bronił realizmu w epistemologii, jest już czystą kpiną”. Tenże, „Karl Popper zdeprecjonowany", Filozofia Nauki, 17 (V, 1997).
} 
które sam Watkins argumentuje raczej kwieciście niż nazbyt ściśle. Zacytujmy:

Anioł Prawdy powiedział mi, że $V s(c i)>V s(c j)$, i gdyby ustalono nagrodę za prawidłowe odgadnięcie, która z hipotez przejdzie pozytywnie próbę tego eksperymentu (...), to byłbym szalony nie stawiając na $c_{i}{ }^{30}$.

Widać, że nie chodzi tu o dedukcyjne zależności, a o psychologiczne oddziaływanie, poparte przykładem z życia codziennego, w którym niejednokrotnie nie kierujemy się względami logicznymi ${ }^{31}$. Główna słabość Watkinsowego argumentu została przedstawiona nieomal explicite: ów „Anioł Prawdy” stanowi dokładnie ten czynnik, którego nie mamy do dyspozycji i mieć nie możemy, bo stanowiłby narzędzie odbierające metodzie naukowej charakter hipotetyczny.

Watkinsowi najwyraźniej umknął fakt, że prawdoupodobnienie określone zostało przez Poppera jako wartość względna. Wyznaczając stopień przybliżenia do prawdy teorii, wbrew pozorom nie zestawiamy ze sobą prawdy (jako teorii prawdziwej) z hipotezą, którą znamy i aktualnie testujemy. Tym, co naprawdę porównujemy, by określić stopień prawdoupodobnienia, to teoria przed i po wyeliminowaniu błędów. Skoro dana hipoteza wcześniej nie radziła sobie z jakimś problemem, a po skorygowaniu wyjaśnia go lepiej, to sądzimy, że zaszedł postęp w nauce; to określamy mianem postępu. Nie ma znaczenia, że wszechobejmującej i ostatecznej prawdy aktualnie nie znamy, a nawet zapewne nigdy nie poznamy. W sytuacji, gdy możemy zaobserwować takie symptomy, jak: dokładność i szczegółowość przewidywania, przetrwanie testów i umożliwienie kolejnych, tłumaczenie większej ilości faktów

\footnotetext{
${ }^{30}$ J. Watkins, dz. cyt., s. 230 ..

${ }^{31}$ To można najjaskrawiej uwidocznić w związku z rachunkiem prawdopodobieństwa. Przykładowo, kto mając trafić sześć liczb z przedziału 1 do 100, wolałby wypełnić dwa kupony rzędami: „1-2-3-4-5-6” i ,7-8-9-10-11-12”, niż mając do dyspozycji tylko jeden kupon, wybrać „naprawdę losowe” liczby, jak: „45-72-5-83-11-92”?
} 
czy generowanie nowych związków między problemami - wówczas nikt nie sądzi, że zachodzą one przypadkowo, lecz że przybliżono się do prawdy. Mamy dobre racje, czy też to nazywamy mianem „dobrych racji”, że zrobiliśmy krok do przodu.

Trudno nie spostrzec, że rozumowanie analogiczne do przytoczonego w ostatnim cytacie można przeprowadzić dla kategorii koroboracji: gdyby $t 1$ przechodziła pomyślnie testy, którym nie można poddać $t 2$, i gdyby ustalono nagrodę za prawidłowe odgadnięcie, która $\mathrm{z}$ teorii sprawdzi się w kolejnym eksperymencie, to byłoby szaleństwem nie postawić na pierwszą z hipotez (w gruncie rzeczy tak mniej więcej sądzi sam Watkins). Odpowiedź na zarzut o indukcyjny charakter wnioskowania o przyszłości (mimo iż koroboracja dostarcza informacji jedynie o przeszłych stanach świata, a zasada indukcji została odrzucona) dotyczy przede wszystkim problematyczności pierwszego przejścia: od powtarzanego doświadczenia do wartości hipotezy. Prawdoupodobnienie nie ma dostarczać racji dla powiązania ze sobą koroboracji i prawdy. Dlaczego wierzymy w przyszłe dobre zachowanie, to problem psychologiczny. Nikt w to wierzyć nie broni, ale bez tego też się można obyć i nie ma ku temu racji w sensie logicznym.

Pytanie, jak rozpoznać, że miało miejsce przybliżenie do prawdy, różni się od kwestii: skąd wiemy, że teoria przybliżyła się do prawdy (o ile to zrobiła). Określenie symptomów, po których intuicyjnie stwierdza się wzrost prawdoupodobnienia, w zasadzie nie jest podważalne, o ile uzna się, że po prostu temu przypisuje się miano poznania w ramach racjonalnej wspólnoty ludzi. Czym innym jest pytanie o źródła wiedzy, że teoria $t 2$ jest bliższa prawdzie niż $t 1$. Tymczasem możliwość dysponowania tego rodzaju przesłankami oznaczałaby, że posiedliśmy znajomość niepodważalnego i kompletnego systemem zdań bazowych; od tego momentu nauka mogłaby się rozwijać w zasadzie bez eksperymentów. Być może do tego dałoby się sprowadzić główną oś Hume'owskiej krytyki indukcji: poznania naukowego nie cechuje pewność; w rzeczy samej, ale z dzisiejszego (i Popperowskiego) punktu widzenia to nie jest żaden zarzut. 
Słowem, poszukiwanie racji w sensie logicznym dla związku między koroboracją a zbliżaniem się do prawdy - do których to racji, jako indukcyjnych i nieprawomocnych, zdaniem Watkinsa Popper nie chce się przyznać, a jednak formułuje metodologię, która miałaby zawierać je implicite - wykracza poza to, co zwie się nauką. Na gruncie koncepcji Poppera można zaryzykować tezę, że jedyną podstawą racjonalności, jeśli już koniecznie trzeba jakąś wskazywać, jest nadzieja na zbliżanie się do prawdy.

John Watkins nie uznaje tego za żaden przyczynek do przezwyciężenia sceptycyzmu, bo jak pisze Lakatos: „czy Pirron lub Hume mieliby coś przeciwko byciu «serio» lub żywieniu «nadziei»?" 32 . Kontynuujacc to spostrzeżenie: choć nawet Hume nie może nikomu zabraniać żywienia określonej nadziei, to z drugiej strony patrząc nawet Popper nie może uzasadniać czegokolwiek, nakazując żywić podobne nadzieje. Przyjmując taki punkt wyjścia, postulowanie przez Feyerabenda rozdziału nauki od państwa, „tak jak to obecnie uczyniono z religią" ${ }^{33}$, można uznać za całkiem zrozumiałe. Jakkolwiek dziwaczny może wydawać się ten pomysł, faktem jest, że podczas gdy świeckie państwo wydaje się we współczesnej Europie oczywistością, to nikt nie potrafi wyobrazić sobie sytuacji, w której na przykład wolno posyłać dzieci do szkoły, gdzie zamiast biologii, fizyki i chemii naucza się astrologii, wróżenia z fusów i przywoływania duchów. Tymczasem zgadzamy się tylko, że prawda jest jedynym, powszechnym i niehipotetycznym, celem każdego poznania, bo tak zakłada nasz język. Jednakowoż choć wszyscy dążymy do prawdy obiektywnej, to nikt nie ma obowiązku podzielać cudzych nadziei; to z kolei zakłada pojęcie nadziei.

Wniosek jest następujący: choć faktem jest, że nie można wnioskować o przybliżeniu do prawdy danej hipotezy z testów, które przeszła, a ze stopnia prawdoupodobnienia o przyszłym zachowaniu teorii $\mathrm{w}$ testach, to jednak trzeba mieć na to nadzieję,

\footnotetext{
${ }^{32}$ I. Lakatos, Pisma z filozofii nauk empirycznych, dz. cyt., s. 272.

${ }^{33}$ P. Feyerabend, Przeciw metodzie, Siedmioróg, Wrocław 1996, s. 239. Por. tamże, s. 239-251.
} 
jeśli się nie chce znaleźć poza ramami racjonalnej dyskusji. Jednak te granice w praktyce okazują się znacznie węższe i bardziej arbitralne, określając nie tylko, w co wierzyć warto, ale także których nadziei podzielać nie wypada.

Popperowskie rozwiązanie problemu rzeczywiście wyjaśnia, dlaczego mimo negatywnych rozstrzygnięć warto kontynuować grę naukową: jak w zakładzie Pascala, nieustannie ryzykujemy, ale w taki sposób, że możemy zyskać (wiedzę) lub nic specjalnie ważnego nie stracić. Jeśli jednak sprowadzimy negatywne rozstrzygnięcia odnośnie zasady indukcji do takiej właśnie „etyki poznawczej" - czyli: co powinno się robić, na co należy mieć nadzieję, jak wygląda racjonalna dyskusja - do Katechizmu Dobrego Racjonalisty, a nie zasad, które do poznania niezawodnie prowadzą, wówczas trudno stwierdzić, dlaczego Hume'owsko-Popperowskie ostrze, zabraniajacce praktyk indukcyjnych w nauce, nie miałoby sięgać także życia codziennego.

To, że dana zasada działała w przeszłości i że przyzwyczailiśmy się do jej stosowania, nie zawsze jest przesłanką za tym, by dalej ją w działaniu praktycznym stosować. Powinno się z nią, wbrew intuicjom i skostniałym przyzwyczajeniom, zerwać, jeśli odkryto, że uderza ona w sferę etyczną. Co z tego, że zasada indukcji działała dotychczas (a wiec żaden „skandal indukcji”, żadne wykazanie jej logicznej nieprawomocności nie zmusi nas do Wittgensteinowskiego „wkładania ręki w ogień")? Możemy podać dowolną ilość ,zasad”, które działały w przeszłości, a jednak zostały (miejmy nadzieję, że nieodwołalnie) porzucone. Doskonale sprawdzało się niewolnictwo, społecznie korzystny był model rodziny, w którym żona podporządkowana była mężowi, zapewne praktyczne okazywało się niedopuszczanie kobiet do wyższej edukacji czy pracy zawodowej, bo oznaczało, że miały możliwość częściej rodzić dzieci, spędzać z nimi więcej czasu, a być może same w tej roli były szczęśliwsze. Postępowanie według wymienionych wzorców „działało”, podobnie jak działała rozumiana po Hume'owsku zasada indukcji. Poszkodowane z dzisiejszego punktu widzenia jednostki być może wcale nie postrzegały swojej sytuacji 
w ten sposób, a mimo to wymienione reguły porzucone zostały ze względów etycznych, niezależnie od społecznych konsekwencji.

\section{Wnioski}

Postawiony we wstępie problem dotyczył pozornego nawrotu do indukcjonizmu, przez powiązanie koroboracji i prawdoupodobnienia, a więc odniesienie nauki do prawdy. W tym miejscu można pokusić się o postawienie hipotezy odnośnie linii podziału między filozofami zajmującymi się problemem indukcji. Część z nich, jak Popper, Watkins czy późny Wittgenstein ${ }^{34}$, konstatuje grę naukową, stwierdza: „to nazywamy racjonalnym, tu pozwalamy sobie na nadzieję i tak wygląda krytyczna dyskusja". Inni, w tym Hume, Carnap i Lakatos, żądają dalszych uzasadnień, by uprawomocnić naukę w szerszym kontekście poznania. Dopiero wówczas można poważnie rozpatrywać kwestię sceptycyzmu. W tej drugiej grupie niektórzy się poddają i uznają naukę za nieprawomocną (Hume), kolejni zakładają, że dopiero wprowadzenie zasady indukcji pozwala odnieść naukę do prawdy (Lakatos), a jeszcze inni szukają ugruntowania dla samej indukcji, na przykład w rachunku prawdopodobieństwa (Carnap). Gdzieś na pograniczu tych dwóch nurtów znajduje się Kant, który z jednej strony konstatuje fakt nauki (a nawet jej rzekomą pewność), jednakowoż starając się go wyjaśnić, nie uznaje za stanowisko domyślne sceptycyzmu, z którego wszelkimi metodami należy próbować się oswobodzić ${ }^{35}$.

Popper, pragnąc przezwyciężyć sceptycyzm, zmierzył się z Hume'owską krytyką poznania, wykazując, iż co prawda indukcja w rzeczy samej pozostaje metodą skandalicznie chybioną, to jednak praktykę naukową można wyjaśnić w inny sposób. Lakatos uważał, że ów szczytny zamiar nie powiódł się, bo odniesienie wyników testowania do prawdy może odbywać się jedynie za

\footnotetext{
${ }^{34}$ Zob. L. Wittgenstein, Dociekania filozoficzne, dz. cyt., §325-§326, $\S 466-\oint 483$.

${ }^{35}$ Jednak uzasadnianie zasady indukcji jako apriorycznie obowiązującej dalekie jest od rozgoracczkowanego poszukiwania usprawiedliwienia dla nauki, bo Newtonowska fizyka broni się sama przez się.
} 
pośrednictwem zasady indukcji. Jego zdaniem, Popper nie jest indukcjonistą, a kryptosceptykiem.

Tymczasem z Popperowskiego punktu widzenia można odpowiedzieć, że usprawiedliwienie nauki polega na odparciu stawianych wobec niej zarzutów, a nie na poszukiwaniu twardego gruntu, z którego można by ją wyprowadzić. Skoro nasz jedyny dom stoi na bagnach, to fakt, że w każdej chwili możemy utonąć, nie upoważnia do aktów samobójczych. Równie dobrze może się zdarzyć, że spędzimy w nim całkiem udane życie. Mówiąc mniej obrazowo, a bardziej zrozumiale, schematy dedukcyjne (w miejsce indukcyjnych) są satysfakcjonujące nie dlatego, że możemy je uzasadnić, lecz ponieważ nie potrafimy ich obalić; jak dotychczas sprawdzały się wystarczająco dobrze. A fakt praktyki naukowej konstatujemy. Odtwarzamy rozwój naukowego poznania (stąd tytuł: Logika odkrycia naukowego), a nie - dokonujemy usprawiedliwienia. Wychodząc od epistemologicznego odpowiednika zasady domniemania niewinności, stwierdzamy, że jak na razie nie ma powodów, by umieszczać naukę na ławie oskarżonych. Indukcja, owszem, powinna się tam znaleźć, aby można było wydać wyrok skazujący, oparty na poszlace, iż zastosowanie zasady indukcji nie prowadzi do rozwoju wiedzy naukowej.

Co zatem doń prowadzi, skoro nie ma możliwości wnioskowania, w sensie logicznym, z koroboracji o prawdoupodobnieniu? Odpowiedź jest prosta: suponowanie, jakoby nauka miała zbliżać się do prawdy, oznacza jedynie konieczną nadzieję, która co prawda nie aspiruje do bycia wiedzą obiektywną ${ }^{36}$, to jednak nie jest redukowalna do subiektywnego poczucia (jako krytykowalna

\footnotetext{
${ }^{36}$ Skoro, jak twierdzi Wittgenstein, każde wyjaśnienie ma swój kres (por. tenże, dz. cyt., §1), zatem nie jest niespójnym twierdzić, że nawet jeśli posiadamy obiektywną wiedzę o jakichś faktach szczegółowych z zakresu nauk empirycznych (np. o kulistości Ziemi), to już nie musimy posiadać równie mocnych racji na rzecz tego, że „wiemy to, o czym wiemy”. Inaczej mówiąc, twierdzenia nauki mogą być znacznie lepiej ugruntowane niż sama nauka. Popperowskie pale wbite w najbardziej grząskie bagna mogą - a nawet powinny być maksymalnie solidne, by utrzymać stojącą nań budowlę.
} 
i każdorazowo odwoływalna, niezależnie od towarzyszących temu emocji).

Reasumując, nie wydaje się, aby Popper był indukcjonistą, gdyż:

1. Akceptował negatywne rozwiązanie Hume'a odnośnie nieprawomocności wnioskowania z przeszłości o przyszłości,

2. Nie szukał dalszych racji dla przyjęcia hipotezy w postaci przypisywania teoriom prawdopodobieństwa, jak to się działo w przypadku Carnapa,

3. Nie popełnił błędów, sugerowanych przez Watkinsa, wnioskując z koroboracji o prawdoupodobnieniu za pomocą zmodyfikowanej zasady indukcji - wszak nadzieja nie jest wiedzą.

Popper nie jest też sceptykiem, ponieważ:

1. Przezwyciężył negatywne rozwiązanie Hume'a, wykazując, że nauka może rozwijać się bez indukcji,

2. Zaś zarzuty Lakatosa wydają się chybione, gdyż nie ma powodów, by odrzucać nadzieję na przybliżanie się do prawdy w wyniku praktyki koroborowania.

Tytułem podsumowania, można powiedzieć, że choć w świecie, w którym zasada indukcji okazałaby się prawomocna, zapewne łatwiej byłoby sformułować ścisłe kryteria przekładania koroboracji na stopień prawdoupodobnienia (który rzeczywiście oznaczałby wówczas bezwzględną odległość teorii od prawdy), to nawet w tym miejscu, w którym przyszło nam żyć i poznawać, nie musimy załamywać rąk, wybierając między instrumentalizmem a skrajnym sceptycyzmem. Nasza nadzieja jest uprawniona, bo „cóż może usprawiedliwić pewność bardziej niż sukces?"37.

${ }^{37}$ L. Wittgenstein, Dociekania filozoficzne, dz. cyt., §324. 


\section{Bibliografia}

1. Carnap R., Filozofia jako analiza języka nauki, PWN, Warszawa 1999.

2. Chmielewski A., Filozofia Poppera. Analiza krytyczna, wyd. Uniwersytetu Wrocławskiego, Wrocław 1995.

3. Hume D., Traktat o naturze ludzkiej, t. I, PWN, Warszawa 1963.

4. Krajewski W., „Karl Popper zdeprecjonowany”, Filozofia Nauki, 17 (V, 1997).

5. Lakatos I., Pisma z filozofii nauk empirycznych, PWN, Warszawa 1995.

6. Nekrašas E., Wiedza prawdopodobna, PWN, Warszawa 1992.

7. Popper K.R., Logika odkrycia naukowego, PWN, wyd. II, Warszawa 2002.

8. Popper K.R., Nieustanne poszukiwania. Autobiografia intelektualna, Znak, Kraków 1997,

9. Popper K.R., Wiedza obiektywna. Ewolucyjna teoria epistemologiczna, PWN, Warszawa 1992.

10. Watkins J., Nauka a sceptycyzm, PWN, Warszawa 1989.

11. Wittgenstein L., Dociekania filozoficzne, PWN, Warszawa 2008.

12. Feyerabend P., Przeciw metodzie, Siedmioróg, Wrocław 1996. 


\section{Abstract}

\section{Why Popper is not a crypto-inductionist}

The article is an attempt to answer the question whether the result of the connection between corroboration and verisimilitude is an inductive element in the Popperian methodology. For this purpose the essay collates Karl Popper's view with David Hume's scepticism and inductionism of Rudolf Carnap. Further on the paper analizes the compromising" (for inductionism and critical falsificationism) proposition of Evaldas Nekrašas. The article also contains a presentation of Imre Lakatos' allegation of Popper's scepticism and the accusation of inductionism as formulated by John Watkins. The study of the disputes between the philosophers leads to the conclusion that the critical views are baseless. The final hypothesis is that these are not the right ways of proving the allegations of crypto-inductionism.

Keywords: Karl Popper, David Hume, Rudolf Carnap, John Watkins, induction, verisimilitude, truthlikeness, probability, corroboration, confirmation, scepticism 